\title{
Atopy in parents of children dying with sudden infant death syndrome
}

\author{
N WARNASURIYA, M A P S DOWNHAM, A SKELTON, M W TURNER, AND \\ J F SOOTHILL
}

Department of Child Health, University of Newcastle upon Tyne, and Institute of Child Health, London

SUMMARY 36 parents of infants who had died suddenly did not differ in frequency of atopic symptoms, immediate skin tests, IgE, IgE antibody, immunoglobulin G, A, and M, or yeast opsonisation, from 36 matched controls, although atopy was common (about half had atopy in both groups).

\begin{abstract}
Allergy to an environmental antigen, particularly cows' milk, is one of many explanations for sudden infant death syndrome (SIDS). ${ }^{1}$ This suggestion has been supported by a strong family history of atopic disease in a retrospective survey of SIDS, ${ }^{2}$ and a high prevalence of IgE antibodies to Dermatophagoides pteronyssinus, Aspergillus fumigatus, and bovine $\beta$-lactoglobulin in cases of SLDS ${ }^{3}$. Atopy is an antigen-nonspecific vulnerability to react damagingly to environmental allergens which results from immunodeficiency, ${ }^{4}$ so the association of SIDS with atopy raises the possibility that sudden death could be due to such a reaction to one or more antigens, or that it could be an independent effect of the underlying immunodeficiency. ${ }^{5}$

If atopy is a common factor in SIDS, it might be possible to predict, from family history, children at high risk and to protect such children by avoiding contact with the antigen. We have therefore carried out a controlled study of atopy in parents of children who have died suddenly and unexpectedly. The assessment of atopy included history of atopic symptoms, serum IgE antibodies, and, for the postulated underlying immunodeficiency, immunoglobulin concentrations, and yeast opsonisation.
\end{abstract}

\section{Methods}

Parents of 19 infants who had died suddenly were studied. In two families only one parent was available, so 36 adults were studied. Blood was obtained from 35 , but in one the volume was too small for all the tests. All the deaths had been in Newcastle in the period 1974-6 and had been investigated in the Newcastle Survey of Deaths in
Early Childhood $;^{6}$ each conformed with the widely accepted definition of SIDS, being sudden unexpected deaths not explained after full clinical investigation and detailed necropsy. The parents were visited at home, the study was explained, and their consent obtained. They were asked to enlist the co-operation of a couple, within 10 years of their own ages, to act as controls. Two families could not do this, so control couples were obtained from the child health clinic nearest to their homes. None of the control parents had lost children with SIDS.

At a second visit, each parent and control was questioned for a history of atopy, using a standardised interview questionnaire (Appendix), which had questions about illnesses other than atopy in an attempt to reduce bias. If clarification of any question was needed, this was given in a preplanned standard manner. Skin prick tests were carried out in the right forearm using 5 antigens (Bencard: D. pteronyssinus, mixed grass pollen (2B), cows' milk, egg, shell fish, and control). The tests were read after 15 minutes, and the diameter of any weal was recorded in millimetres. Weals of more than $3 \mathrm{~mm}$ in diameter were taken as positive. $5 \mathrm{ml}$ of clotted blood was collected by venepuncture.

Serum IgG, IgA, and IgM were measured by radial immunodiffusion. The serum IgE was measured by a modification of the double antibody method of Nye et al., ${ }^{7}$ and IgE antibody to extracts of $D$. pteronyssinus and Timothy grass pollen (kindly supplied by Bencard), and cows' milk $\beta$-lactoglobulin (Sigma) by a modification of the method of Wide et al. ${ }^{8}$ Opsonisation of bakers yeast was measured by the method of Soothill and Harvey. ${ }^{9}$ Statistical analysis was by Fisher's exact test, and $t$ test on logged data. 


\section{Results}

About half of the SIDS parents and about half of the controls gave a history of at least one of the allergic diseases in the questionnaire, and about half of both groups gave positive $(>3 \mathrm{~mm})$ responses to at least one of the 5 antigens (prick tests with the control solution were all negative) (Table 1). Results of the serum IgG, A, M, and E, IgE antibody to $D$. pteronyssinus, Timothy grass pollen, cows' milk $\beta$-lactoglobulin, and yeast opsonisation were remarkably similar in both groups (Table 2), and, except in the case of IgE, all the results were similar to those in an earlier control series. None of the differences between the two groups was statistically significant. Similar numbers in each group had levels that were outside the diagnostic limits for our department for each test (Table 3).

\section{Discussion}

Atopy is a highly familial phenomenon, ${ }^{4}$ and so parents of children with a syndrome associated with

Table 1 Atopic symptoms and immediate prick tests to selected antigens in parents of infants dying suddenly, and controls

\begin{tabular}{lcc}
\hline & $\begin{array}{c}\text { Parents } \\
(n=36)\end{array}$ & $\begin{array}{l}\text { Controls } \\
(n=36)\end{array}$ \\
\hline A topic symptoms & 3 & 4 \\
$\quad$ Asthma & 3 & 4 \\
Eczema & 4 & 9 \\
Rhinitis & 9 & 11 \\
Urticaria & 16 & 19 \\
One or more & & \\
Positive skin tests & 12 & 13 \\
$\quad$ D. pteronyssinus & 8 & 10 \\
Timothy grass pollen & 4 & 5 \\
Cows' milk & 2 & 4 \\
$\quad$ Egg & 4 & 8 \\
Shell fish & 15 & 17 \\
One or more & & \\
\hline
\end{tabular}

Table 3 Numbers of parents of SIDS infants and controls with high $(>100 \mathrm{IU} / \mathrm{ml})$ or very high $(>400 \mathrm{IU} / \mathrm{ml}) \mathrm{IgE}$, positive $\mathrm{IgE}$ antibody $(>1.6 \times$ counts found by cord serum) to $D$. pteronyssinus, Timothy grass pollen, or cows' milk $\beta$-lactoglobulin, or defective yeast opsonisation $(<2.5$ yeasts per polymorph)

\begin{tabular}{lll}
\hline & $\begin{array}{c}\text { Parents } \\
n=35\end{array}$ & $\begin{array}{l}\text { Controls } \\
n=36\end{array}$ \\
\hline High IgE & 13 & 13 \\
Very high IgE & 5 & 6 \\
Positive IgE antibody to D. pteronyssinus & 3 & 4 \\
Positive IgE antibody to Timothy & 5 & 7 \\
$\quad$ grass pollen & 5 & \\
Positive IgE antibody to cows' milk & 2 & 3 \\
$\quad \begin{array}{l}\beta-1 \text { lactoglobulin } \\
\text { Yeast opsonisation defective }\end{array}$ & 1 & 2 \\
\hline
\end{tabular}

atopy are likely to be atopic. Reports from Australia that infants who have died suddenly have more IgE and IgE antibody, ${ }^{3}$ and a family history of atopy, ${ }^{2}$ suggested that SIDS might have such association. The observation of degranulation of mast cells in lung tissues of SIDS infants ${ }^{10}$ would be consistent with this view, although it is also open to other explanations. The association of SIDS with certain blood groups, and with artificial infant feeding, ${ }^{11}$ could also have an immunological explanation. In this study of parents of infants who died suddenly, atopy was not more common than in the controls, whether by symptom, prick test, IgE, or IgE antibody. We should comment however, that the frequency of atopy was surprisingly high in both groups. We have no satisfactory explanation for this, but we think that this system of matched control constitutes as satisfactory a control as is possible, despite the small numbers, since it minimises the effect of environmental variation. We were careful to avoid introducing bias by not telling the subjects what we were looking for; the letter sent to them made no mention of allergy and the phrase used was that we were studying 'patterns of illness varying between

Table 2 Immunoglobulin concentrations $(I U / m l), I g E$ antibodies to D. pteronyssinus, Timothy grass pollen, and cows' milk $\beta$-lactoglobulin ( $\%$ counts bound), and yeast opsonisation (yeasts per polymorph), expressed as antilog of mean of logged data, and observed range, for parents of infants dying suddenly, and controls

\begin{tabular}{|c|c|c|c|c|}
\hline & \multicolumn{2}{|c|}{ Parents $(n=35)$} & \multicolumn{2}{|c|}{ Controls $(n=35)$} \\
\hline & Mean & Observed range & Mean & Observed range \\
\hline $\begin{array}{l}\text { IgG } \\
\text { IgA } \\
\text { IgM } \\
\text { IgE } \\
\text { IgE antibody to } D \text {. pteronyssinus } \\
\text { IgE antibody to Timothy grass pollen } \\
\text { IgE antibody to cows' milk } \beta \text {-lactoglobulin } \\
\text { Yeast opsonisation }\end{array}$ & $\begin{array}{l}133 \\
120 \\
125 \\
59 * \\
0 \cdot 53 \\
0 \cdot 48 \\
0 \cdot 56 \\
4 \cdot 21\end{array}$ & $\begin{array}{r}84-196 \\
56-224 \\
56-304 \\
<4->400^{*} \\
0 \cdot 21-4 \cdot 02 \\
0 \cdot 30-5 \cdot 34 \\
0 \cdot 43-2 \cdot 54 \\
2 \cdot 04-5 \cdot 38\end{array}$ & $\begin{array}{l}126 \\
110 \\
137 \\
54 \dagger \\
0 \cdot 51 \dagger \\
0 \cdot 51 \\
0 \cdot 55 \dagger \\
4 \cdot 03 \dagger\end{array}$ & $\begin{array}{l}76-172 \\
42-204 \\
52->450 \\
<4->400 \dagger \\
0 \cdot 25-2 \cdot 22 \dagger \\
0 \cdot 29-3 \cdot 93 \\
0 \cdot 37-18 \cdot 1 \dagger \\
0 \cdot 40-5 \cdot 28 \dagger\end{array}$ \\
\hline
\end{tabular}

$* n=34 . \dagger n=36$. 
different families'; in the questionnaire, questions about atopy were with ones about other diseases. We can see no reason why the genetic predisposition for atopy should have been particularly chosen by the control group, and any environmental factor would probably be similarly shared.

The association of atopy with immunodeficiency ${ }^{4}$ expands the possible relationship between sudden infant death and atopy; perhaps the link arises, not from the allergic element, but from other effects of the immunodeficiency (for example, susceptibility to respiratory infection). The series of Turner et al. ${ }^{3}$ did indeed have evidence of rather low serum $\operatorname{Ig} \mathrm{A}^{5}$ which may well have been the transient IgA deficiency clearly related to atopy. ${ }^{4}$ Such a transient defect would not generally be detectable in adult life, but

Appendix
Parental atopy questionnaire
Name:
Address:
Number of children: alive:
Ages of live children: 1 dead:
Number of people in household:
Number of rooms (excluding bathroom and kitchen unless the latter
is used as a living room)
Name of matched couple: Father:
Date of birth:
Place of birth:
Race:

\section{References}

1 Parish W E, Barrett A M, Coombs R R A, Gunther M, Camps F E. Hypersensitivity to milk and sudden death in infancy. Lancet 1960; ii: 1106-10.

2 Mulvey P M. Cot death survey. Anaphylaxis and the house dust mite. Med J Aust 1972; ii : 1240-4.

3 Turner K J, Baldo B A, Hilton J M N. IgE antibodies to Dermatophagoides pteronyssinus (house dust mite), Aspergillus fumigatus, and $\beta$ lactoglobulin in sudden infant death syndrome. $\mathrm{Br}$ Med J 1975; i: 357-60.

${ }^{4}$ Soothill J F, Stokes C R, Turner M W, Norman A P, Taylor B. Predisposing factors and the development of reaginic allergy in infancy. Clin Allergy 1976; 6: 305-19.

5 Turner K J, Soothill J F. Letter: Sudden infant death syndrome and immunodeficiency. Lancet 1975; ii: 917.

6 Working Party for Early Childhood Deaths in Newcastle. Newcastle survey of deaths in early childhood $1974 / 1976$, with special reference to sudden unexpected deaths. Arch Dis Child 1977; 52: 828-35.

7 Nye L, Merrett T G, Landon J, White R J. A detailed investigation of circulating IgE levels in a normal population. Clin Allergy 1975; 5: 13-24. some might well have a more permanent immunological defect, and the yeast opsonisation defect, observed in 1 in 4 atopics, ${ }^{12}$ and apparently inherited as an unusual dominant inheritance, ${ }^{9}$ certainly should be. Such defects could well underlie the high frequency of antibody to cows' milk in SIDS infants. ${ }^{1}$ There was no excess of either of these immunodeficiencies in our series.

It is likely that there are several causes of SIDS, and the frequency of the different causes will probably differ from place to place, so our data in no way refute the Australian studies, or disprove the possibility that some of the children in our series died of allergy, or of another immunodeficiency-related disease. Unfortunately however, this negative study does not help to identify at-risk children.

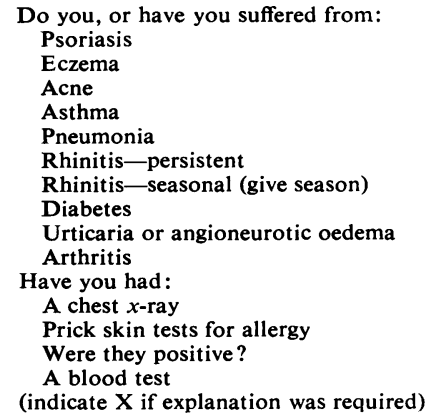

8 Wide L, Bennich $\mathrm{H}$, Johansson S G O. Diagnosis of allergy by an in vitro test for allergen antibodies. Lancet 1967; ii: $1105-7$.

9 Soothill J F, Harvey B A M. Defective opsonisation; a common immunity deficiency. Arch Dis Child 1976; 51 : 91-9.

10 Emery J L, Carpenter R G. Pulmonary mast cells in infants and their relation to unexpected death in infancy. In: Robinson R R, ed. SIDS 1974. Toronto: Canadian Foundation for the Study of Infant Deaths, 1974: 7.

11 Carpenter R G, Emery J L. Identification and follow-up of infants at risk of sudden death in infancy. Nature 1974; $250: 729$.

12 Turner M W, Mowbray J F, Harvey B A M, Brostoff J, Wells R S, Soothill J F. Defective yeast opsonisation and C2 deficiency in atopic patients. Clin Exp Immunol 1978; 34: 253-9.

Correspondence to Dr M A P S Downham, Riverside Child Health Project, Atkinson Road Infant School, Newcastle upon Tyne NE4 8XT.

Received 6 September 1979 